\title{
APPLYING PRINCIPLES OF GOOD GOVERNANCE AT HIGHLANDS INTERNATIONAL BOARDING SCHOOL (HIBS) MALAYSIA
}

\author{
Henni Gusfa and Yofrina Octika Gultom \\ Universitas Mercu Buana Jakarta, Indonesia
}

\begin{abstract}
Good governance is one of the factors in improving the quality of education. Some points of good governance in school are to involve all participations of school management, to ensure the use of funds appropriately, and to cooperate with school principals, teachers, and school staffs. The purposes of this program are to inform the significant use of internal communication and to encourage the school members in applying good governance in school. This study is to identify the internal communication existing, the application of good governance, and teacher's competences. The result of this program is to deliver some comprehension and knowledge related to the awareness of good governance in which the benefits are given to the school. This study was applied at Highland International Boarding School (HIBS) Malaysia. The target program of the community service was one day-training and Focus Group Discussion (FGD) which was held at Highlands International Boarding School (HIBS) in Malaysia. The aim of this program is to gain a better management system based on good governance in its work environment. It was found that applying principles of good governance and building internal communication among school members are essential in increasing the school quality.
\end{abstract}

Keywords: Good Governance, Principles, School, Internal Communication, Education

\section{INTRODUCTION}

Good governance is related with the system of rules, practices, and processes by which an institution is firmed and controlled. Good governance in education sector supports effective delivery of education services. Good governance is also related with making decisions for the institutions. Adamu Abbas and Bahtiar (2019) had a research on evaluating the crisis management in school. Some schools have got their international standards; however, some education systems tend to be gaining profit and ignore the quality aspects and good governance elements; for instance school management and foundation have different mission and tends to be not transparent.

The characters of good governance are: (1) Participation. Each person should have a voice in decision-making, either directly or through legitimate intermediate institutions that represent their interests. Such broad participation is built on freedom of association and speech, as well as capacities to participate constructively. (2) Rule of law. Legal frameworks should be fair and enforced impartially, particularly the laws on human rights. (3) Transparency. Transparency is built on the free flow of information. Processes, institutions and information are directly accessible to those concerned with them, and enough information is provided to understand and monitor them. (4) Responsiveness. Institutions and processes try to serve all stakeholders. (5) Consensus orientation. Good governance mediates differing interests to reach a broad consensus on what is in the best interests of the group and, where possible, on policies and procedures. (6) Equity. All men and women have opportunities to improve or maintain their well-being. (7) Effectiveness and efficiency. Processes and institutions produce results that meet needs while making the best use of resources. (8) Accountability. Decision-makers in government, the private sector and civil society organizations are accountable to the public, as well as to institutional stakeholders. This accountability differs depending on the organizations and whether the decision is internal or external to an organization. (9) Strategic Vision. Leaders and the public have a broad and long-term perspective on good governance and human development, along with a sense of what is needed for such development. There is also an understanding of the historical, cultural and social complexities in which that perspective is grounded.

\section{IMPLEMENTATION METHOD}

HIBS has been recognised as a 5 star-school by the Ministry of Education in Malaysia.The school motto is Explore, Enrich, and Excel. This school provides excellent facilities to support teaching and learning process and concerns on the use of English among teachers and students. HIBS also focuses on grooming each and every student and to pave the way for students to be a truly outstanding individual in society.

During the one day-training at HIBS, Haridas, the executive committee of HIBS Malaysia, spoke about the essence of good governance in education sectors and HIBS vision and mission. Henni Gusfa, from Universitas Mercu Buana Jakarta, presented about the principles of good governance in education sector. She said, "School principal and teachers need to build strong relationships with parents. Parents are partners in supporting school 
development, motivating children, and raising student achievement. Since HIBS is a boarding school, the parents can monitor the behaviour, achievement, and social development of their children through online communication with teachers. In addition, a parent-teacher meeting is also needed to build internal communication with parents (Bahtiar,2000).

Focus Group Discussion is aimed to understand better about internal communication (Hola,2006) and good governance and to discuss on how to apply the program results in school activities, activites that help improve internal communication such as having more active activities of appropriate internal communication implemeted, such as: sharing information of the company target, giving directions to the employees, taking rsponsibilities to every demand and job given in which the management should be able to control dan lead the employees in taking steps and making decision.. This program is to identify the internal communication existing in international boarding school, the good governance application in international boarding school, and teacher's competences in good governance.

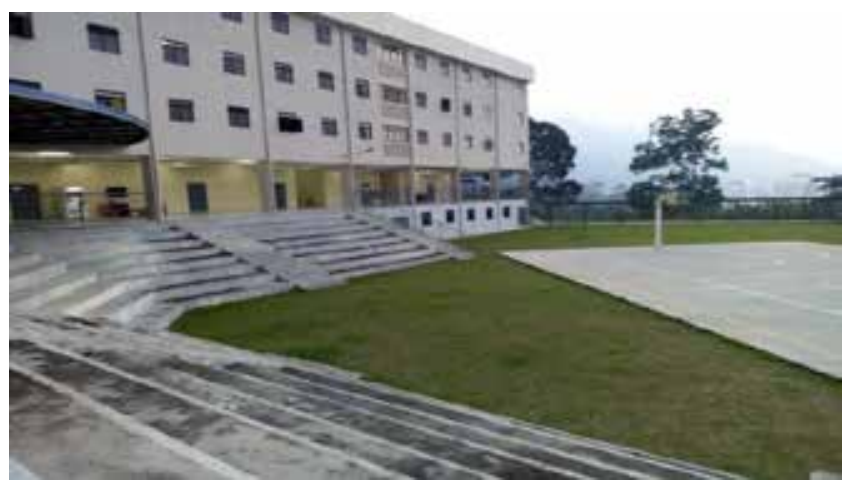

Picture 1. Sport Location

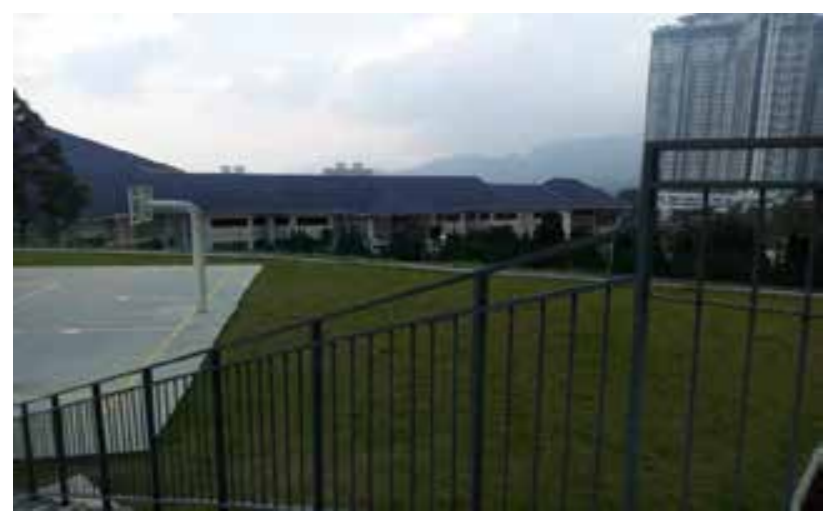

Picture 2. Boarding Location

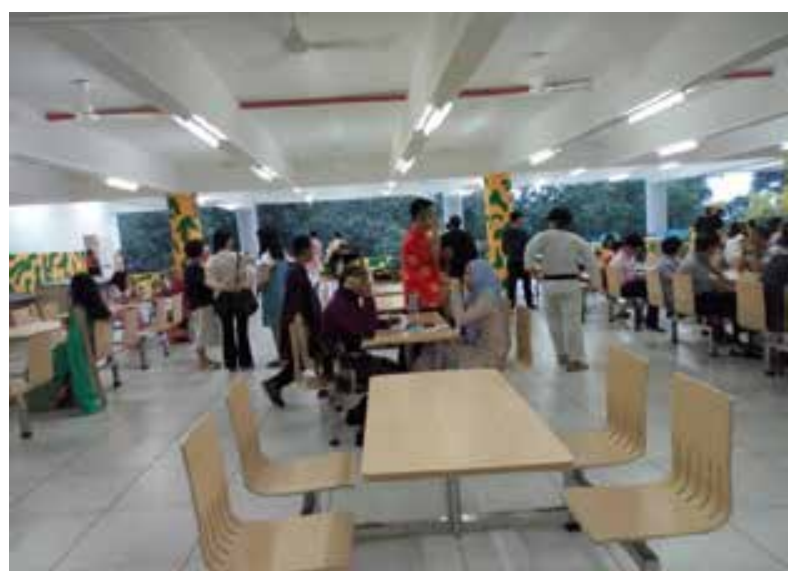

Picture 3. Dining Hall 


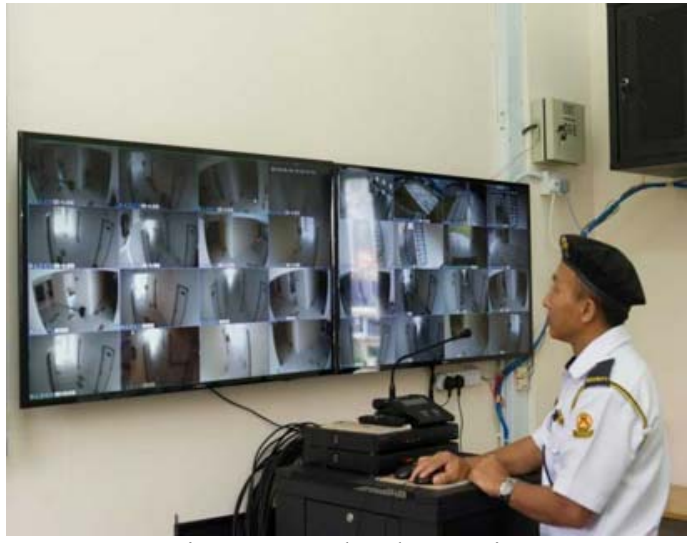

Picture 4. School Security

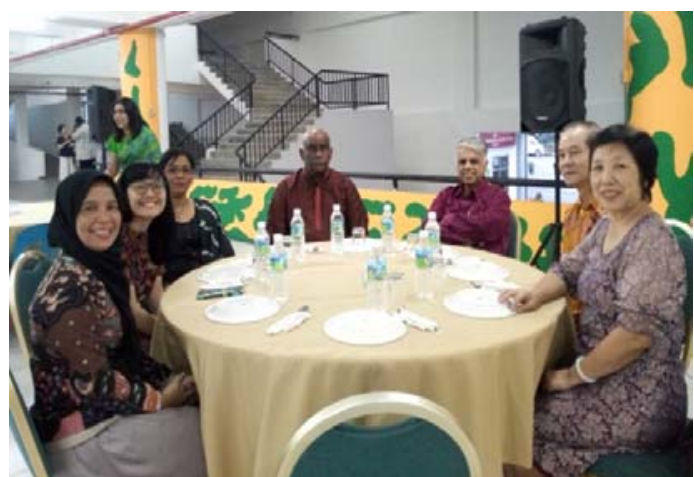

Picture 5. School Principals and Board Members

The steps of the seminar are:

1. Welcoming the speakers and participants

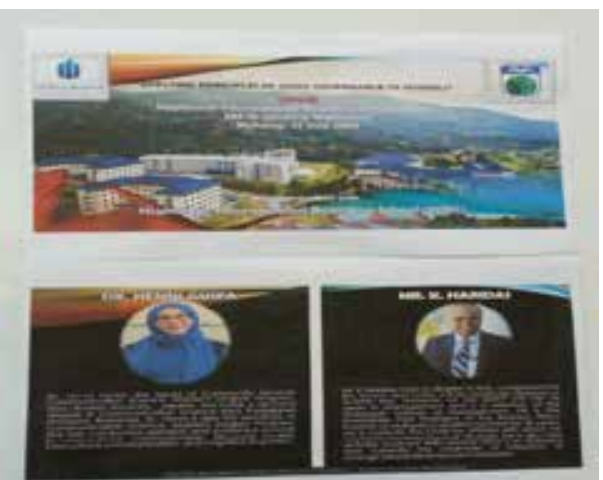

2. Introducing the seminar theme

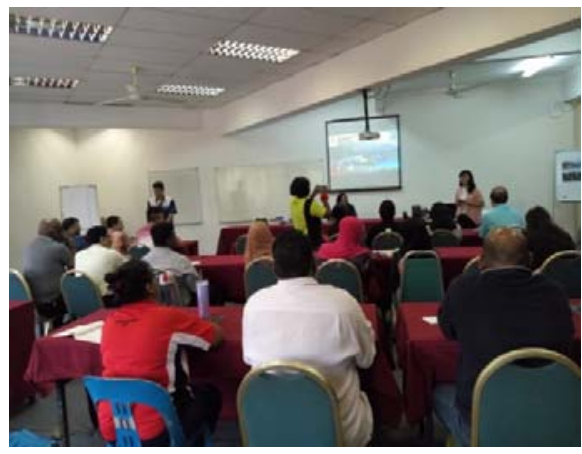

3. Delivering a presentation about the essence of good governance in schools 


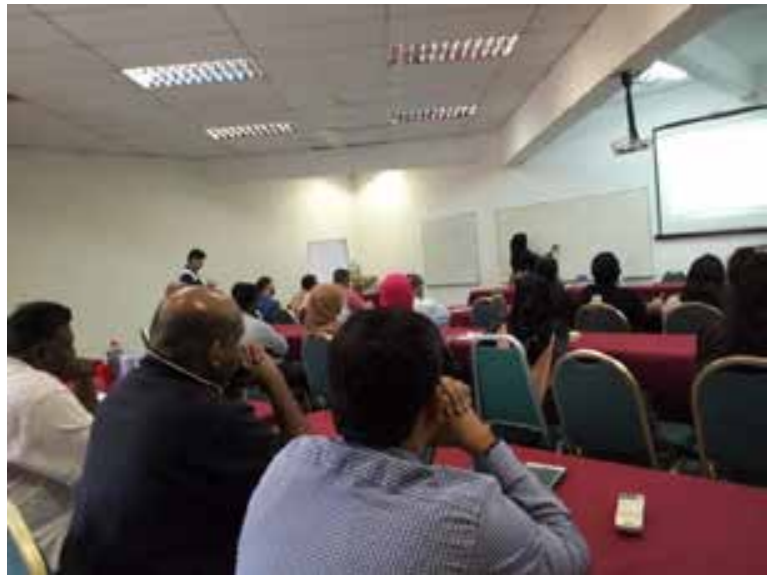

4. Giving certificates and souvenirs from HIBS

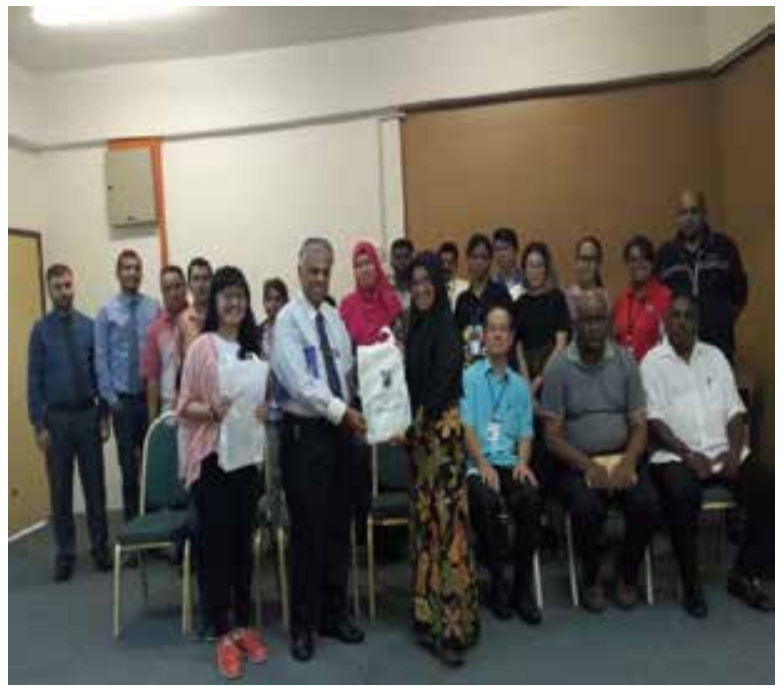

5. Having photo session with HIBS teachers and staffs

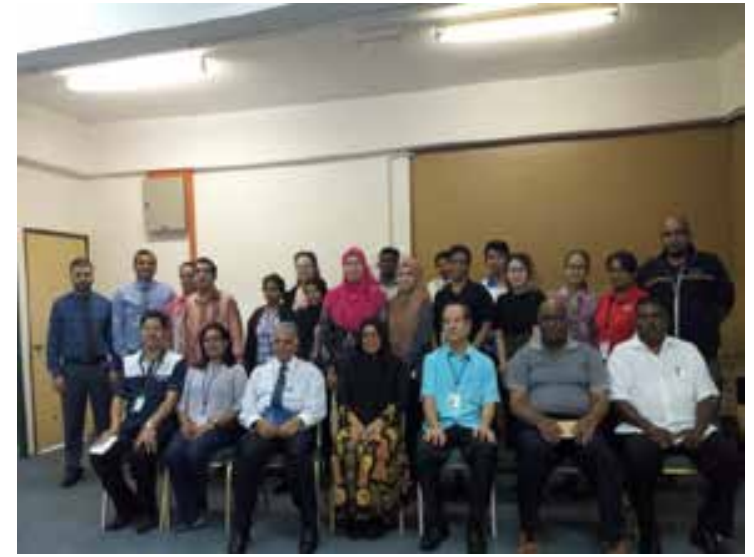

\section{RESULT AND DISCUSSION}

It was found that good governance in education sector is essential in increasing the school quality (Baird,200), the quality of management in schools which can be produced through the internal communication. The internal communication can be carried out by board members, principals, teachers, parents and students as well as the external members. Governance in school and harmonious relationships are also maintained with the effectiveness of online and offline media use. 
Through this program, the problem was identified in order to apply internal communication and good governance in schools. The participants of this program are school members of Highlands International Boarding School Pahang, including school principal, teachers, and school staffs. The program method is to identify the internal communication existing in international boarding school, to identify the good governance application, to identify teacher's competences in good governance, to inform the significant use of internal communication and good governance in school, to persuade the school members in applying good governance in school. The writers suggest on providing communication application among teachers and parents in order that parents are well informed about their children's updates, in which most of the students came from various countries from Asia.

\section{REFERENCES}

Bahtiar, M \& Abbas, Adamu. 2019. A Reliable and Valid Measurement Scale for Assessing Internal Crisis Communication. Malaysia

Baird, M. 2000. The Proper Governance of Companies Will Become as Crucial to the World Economy as the Proper Governing of Countries. Paper

Gunadarma, D. M. 2013. Contoh Kasus Pelanggaran Etika di Perusahaan. https://devimustikagunadarma.wordpress.com/2013/11/08/kasus-pelanggaran-etika/

Hola, J. 2006. The Internal Company Communication. Brno: Computer Press

McKinsey \& Company, 2002, Global Investor Opinion Survey 2002 : Key Findings, July, htth//www.McKinsey.com/Governance

Newell, R. \& Wilson, G. 2002. A Premium for Good Governance. The McKinsey Quarterly, Number 3

UNDP (1997) Governance for Sustainable Human Development. United Nations Development Programme

Turner, J. C., Brown, R. J., \& Tajfel, H. 1979. Social Comparison and Group Interest in Ingroup Favouritism. European Journal of Social Psychology, 9(2), 187-204.

https://hibs.edu.my/ accessed on August, 2019 